\title{
Information Accessibility in Museums with a Focus on Technology and Cognitive Process
}

\author{
Laura B. Martins and Felipe Gabriele \\ Federal University of Pernambuco, Design Department, Recife, Brazil \\ \{laurabm@folha.rec.br, felipegabriele@hotmail.com\}
}

\begin{abstract}
The present article is part of a more broaden study regarding the integrated systems of information. The focus of this research is the informational accessibility in museums under the perspective of the universal design and the ergonomic information and cognition. Its objective is to report the research regarding new information and communication technologies, based on bibliographic researches and synchronic analysis in Brazilian and European museums. This work was carried out under the intention to gather data about the state of the art in the area, aiming to understand it enough to find more proper solutions to be applied in the object of study - the Kahal Zur Israel synagogue.
\end{abstract}

Keywords: Information design, Information ergonomics, Universal design.

\section{Introduction}

One of the main objectives of a system of information is to communicate for the user. The way this information is transmitted will dictate the quality and effectiveness of the system and, to do so, must take into account the fact that there are specific technologies to facilitate the process of assimilation and access.

In Brazil, according to the Census made in 2010[1], there was an increase of $86 \%$ in relation to the Census of 2000, in the quantity of people who declared to have some sort of disability. From around twenty four million habitants, this number jumped to more than forty and five million. At the same time, the Brazilian population had a $12.3 \%$ increase. The inclusion of this population in the several sectors of the everyday life, rather in the social, labor, educational, leisure or others sectors, have been widely discussed and encouraged in the federal, state and municipal scopes through several laws and decrees. However, it is noted that the current legislation doesn't guarantee the inclusion of people with disabilities, turning this into a tough task that has been finding some difficulties, such as the architectonical, informational, educational and organizational barriers.

Considering the human-computer interaction (as human-information interaction), we conceive that, depending on the system, this interaction may have problems of effectiveness. "The problems originate with different people: the end-users who directly experience the consequences of poorly designed systems; the developers who make decisions about system interfaces; the engineers concerned with formulating 
principles, methods and tools for system developers; and the scientists interested in explaining and predicting the behavior of human-computer systems"[2]. Such problems should be anticipated and avoided or, once detected after system application, sought to be repaired the best way possible for the end-users.

Based on this purposes, the universal design is inserted, as affirmed by Soares \& Martins[3], as a way to direct the processes of design towards the comprehensiveness of all the potential users. According to Mace[4], one can define universal design as the project of products and environments able to be used by the largest number of people without the need to be adapted nor of a specialized project. Ergonomics is an important tool, once it enables products, environments and systems of information to be suited to all users, including those with some sort of disability, becoming indispensable for adjusting demands to the specific needs of this population.

In this context, the objective of the present article is to report the gathering of data made regarding new technologies of information and communication to be applied in the museum Kahal Zur Israel Synagogue - as part of the research, current being developed, about information accessibility in museums - through the principles and methods of Ergonomics. Kahal Zur Israel Synagogue is located in Recife, capital of the State of Pernambuco, Brazil.

First synagogue of the America, Kahal Kadosh Zur Israel (Rock of Israel Holy Community) was created during the Dutch domain in the city of Recife, between 1640 and 1641 . The original building was demolished in the early 20th century and, thanks to archeological and cartographic studies, the exact place of the synagogue was discovered. Entirely rebuilt, it was reopened in 2001. Currently it hosts, besides the synagogue, the Jewish Cultural Center of Pernambuco and the Jewish Memorial Museum, where is displayed the history of Jewish communities in Brazil.

Such research gains importance as it focus in quality of life, proposing the strategic development of accessibility to environments and systems of information, to make them compatible with the needs, potentialities and limitations with the performance of all users.

\section{Methods and Techniques}

Thus, it's necessary to deepen into investigations regarding technologies that enable the implementation of systems of information related to accessibility in museums, considering the principles of the universal design. Through the bibliographic researches in brazilian and international articles published in periodicals and conferences alike, besides the survey on the reality of interactive museums and exhibitions in Brazil - Museu da Língua Portuguesa and Museu do Futebol (Portuguese Language Museum and Soccer Museum); England - Tate Modern; Spain - Reina Sofia (Queen Sofia); Italy - a tour through the historical part of Milan; and Museo Virtuale della Memoria Collettiva (Virtual Museum of the Collective Memory) and France - Louvre, a survey was made to know the condition of the art of information and communication technologies, thus aiming at an efficient communication between the information offered and the user. 
For the bibliographic research, means of publication that had relevance in the academic scenario were sought. To do so, initial parameters were determined for periodicals search. Initially, publications with a good rate of impact factor or Qualis A qualification were researched; besides a broad indexing basis, as the Directory of Open Access Journals - DOAJ - and the Capes basis (Coordination for the Improvement of Higher Education Personnel), Brazilian federal department responsible for the academic organization. Besides periodicals, publications of conferences and some essays that had similarities with the subject were analyzed.

\section{Outcomes and Discussions}

Through the issue: how to enable, with the support of the Information and Communication Technologies - ICT, the development of accessibility strategies towards museums - in this case, the Kahal Zur Israel Synagogue - for the access and use of spaces of historical and cultural character to the wide range of population? And, through the survey made, the analyzed technologies are presented.

\subsection{Touchscreens}

Allow a better interaction with the user through an intuitive interface, enhancing the capture of information. There are four types of touchscreen technology: resistive, capacitive, acoustic wave and optical imaging systems. The current most used are the capacitive, which are equipped in the large variety of smartphones and tablets available in the market. Those kind of screens are used, for example, in the Portuguese Language Museum, in São Paulo, Brazil (Fig. 1), through an educational and ludic manner, aiding the user to form words and sentences.

\subsection{Internet}

The world wide web of computers is becoming an ally in disseminating information with an increasingly higher quantity of potential the receptors. May be used to create virtual museums, where the user can access it from anywhere in the world and explore its rooms and expositions. Usually two forms of creation are used. One is the virtually created environment similar to the original, with practically infinite capacities of use and possibilities; while the other one is with the use of images or videos in 360 degrees, where the user may meet all the rooms and works exhibited as he were in the museum itself. Louvre, in Paris, France, is one of the examples of museums which use this technology.

\subsection{Virtual Reality}

An advanced interface technology between a user and a computerized system, with the purpose to create a parallel reality, where the user may interact and have sensations as similar to reality as possible. 


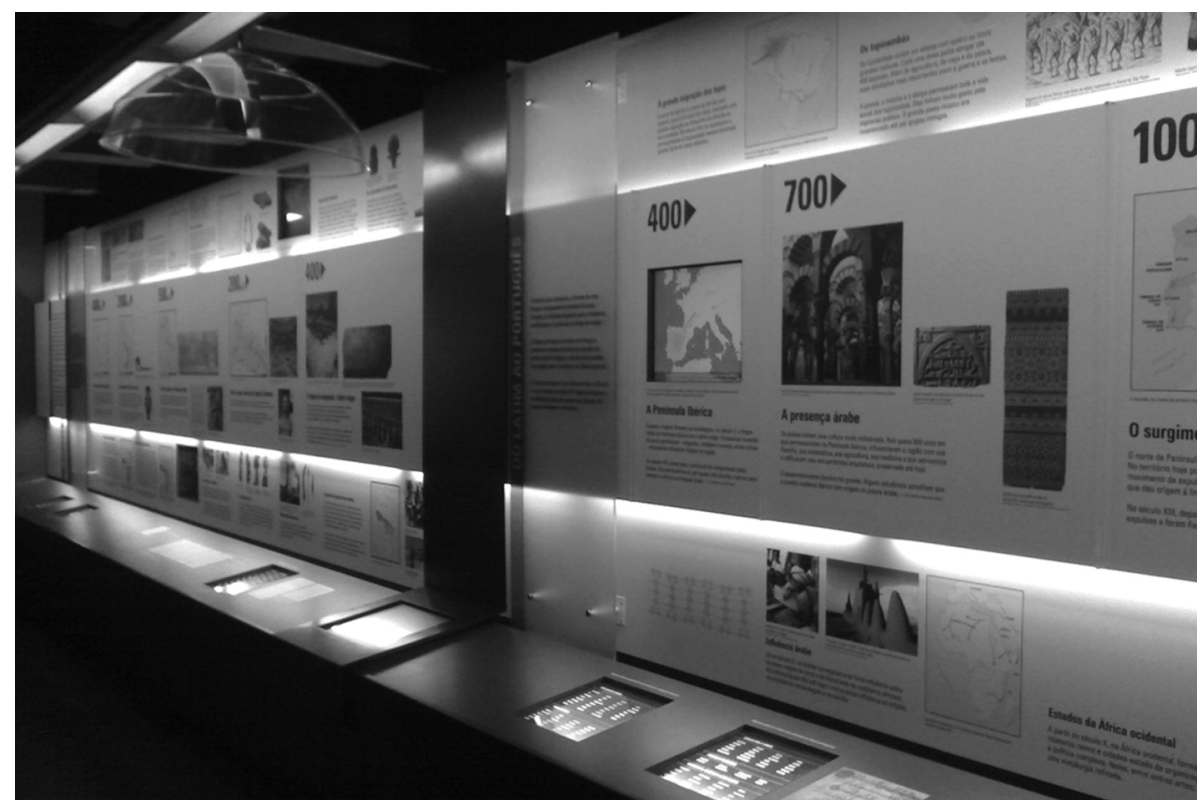

Fig. 1. Portuguese Language Museum. São Paulo, Brazil.

After the creation of a specific virtual environment, to fulfill the proposal, the user access through specific glasses or a helmet, where he is immersed in that environment by his senses, such as vision and hearing. Through the use of special gloves, is also possible to have tactile feeling.

May be used in the creation of fictional settings, as in the technique called Virtual Heritage, used to recreate historical settings and explore them.

\subsection{Audio Guide}

Using a specific device (Fig. 2) or the smartphone itself, the user may listen to explanations about the museum or about the exhibitions.

With the development of a specific applicative or with the recording of a guiding visit through the area to be explored - considering the use by a person with visual impairment - the audio guide is made by introduction stops, welcoming and explanations of use; first level stops, where the main information is given; and second and third level stops, where any other information is given.

The audio guide is used not only in museums but also in historical tours, as for example in Milan, Italy, where the tourist takes a tour while listening to the explanations regarding the places visited through the audio guide. Great European museums, such as the Louvre, allow the user to download for free an application with audio guide direct to their cellphones; the Tate Modern, in London, however, has guided visits where, besides the audio guide, it's also allowed interaction by touch with the exhibited works. 


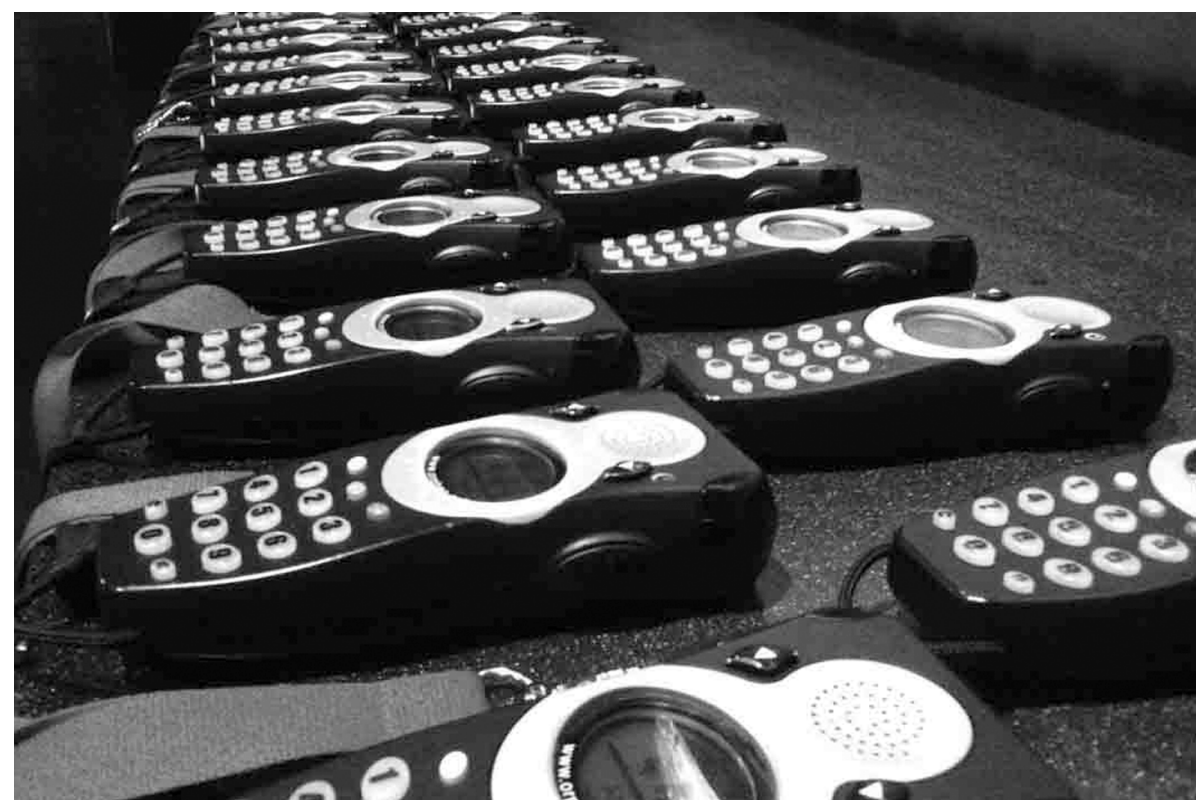

Fig. 2. Example of audio guide

\subsection{Tactile Map}

A map containing relevant information accessible to visual impaired people through embossed elements and writings in Braille (Fig. 3). The same goes to plates written in Braille, used for informational guidance.

The map reproduces bidimensionally the environment, which it is representing with traces, and symbols that represent places and/or embossed obstacles, in a way that may allow the visual impaired to read it with his hands, getting a visual guidance of the environment. There are written information with embossed letters and in braille, making the offered information more easily comprehensible. Tactile map is complemented with other types of inclusive technologies, like the tactile floors.

\subsection{Tactile Floors}

Tactile floors (Fig. 4) are also known as podotactile, which means the sensation through the feet. They serve to assist people with visual impairment to walk, guiding and marking their routes, or alerting them for possible gaps and barriers. As coatings for the floors, they don't work alone, rather with a composition of pieces for a safe walk with autonomy.

In Brazil there are two types of tactile floors, which are described by NBR 9050[5] (Brazilian Norm who defines the edification accessibility) as (a) directional or guiding floor, with the function to guide the user through a pre-defined route; and (b) 


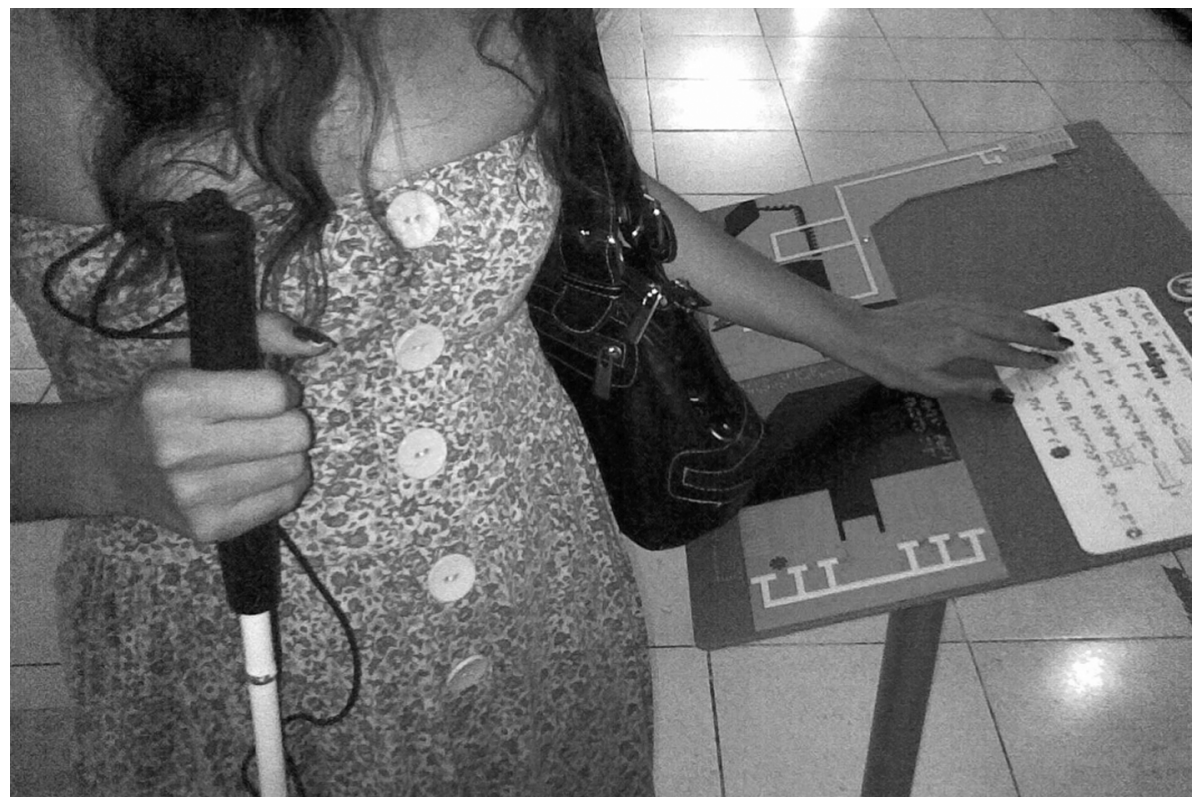

Fig. 3. Example of tactile map

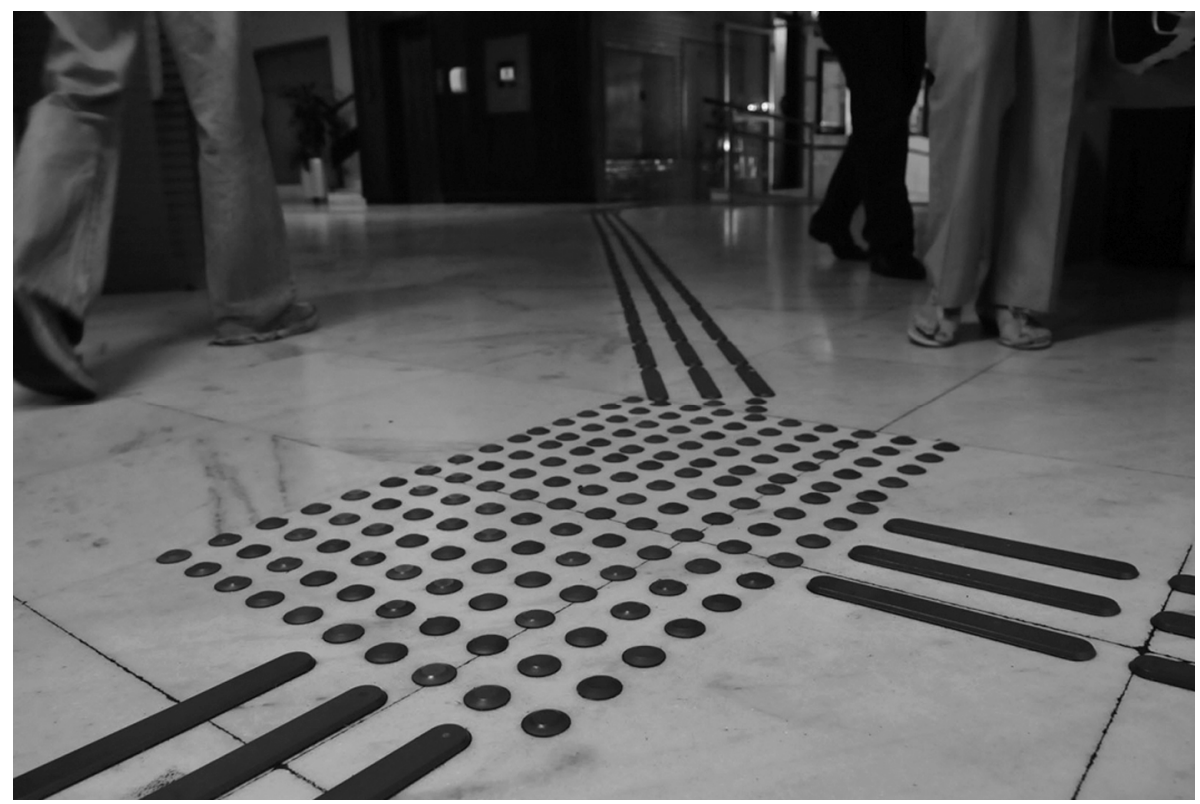

Fig. 4. Example of tactile floor 
awareness floor, with the function to alarm the user about dangers, obstacles, bumps and route changes.

\subsection{Considerations about the ICT}

As affirmed by Muchacho[6], "the ICT are precious instruments in the process of communication between the museum and its audience. Its utilization as a complement of an exhibition comes to facilitate the transmission of the intended message and to gain the attention of the visitant, enabling a new vision of the museology object".

Because it is a subject rarely addressed in the field of information ergonomics, the analysis of positive experiences with the ICT becomes relevant in the research of informational accessibility in museums while it makes possible for an analysis of the rights and wrongs of pre-established informational systems, helping in the future implementation of the Synagogue system of information.

\subsection{Considerations about the Cognitive Process}

Mankind is seen, according to the approach of information processing [1], as a system that receives, processes, transmits, stores and uses information. This approach has emerged since the 1970s, with the aim of investigating the responsibility of basic internal mechanisms in the production of movement and behavior modification in the individual [2]. Over the years the human race begins to acquire a gradual knowledge in the engine process of your body in the same way that, according to Tani et al [2], this whole movement is also essential for cognitive development. We may conclude with these thoughts that the cognitive and motor skills are closely linked in their learning process and progress along the maturity of the individual. In other words, according to Schmidt [3], no matter how cognitive ability may seem, it requires at least one motor feedback, while all motor skill also requires at least a decision prior to your move.

When analyzing motor learning among individuals with a physical disability, you must also take into consideration their cognitive abilities during the process. A difficulty to learn certain movement can be explained by the type of disability and the level of commitment of the same, so some specific methods and approaches should be used to might work around this impasse in the best way possible. The way that an individual who has some physical disability has, inherently, difficult to perform motor tasks, it is necessary that the corresponding and dependent information on some level to such action is as clearly, accurately and objectively as possible, reducing thus, the response time of the reaction and contributing to the overall effectiveness of the system. Taking into account the visual disability, for example, where the user has at his disposal tactile guides that help him to move around independently - or touch screens that allow editing of the information, so text can become enlarged readable for a user with low vision (according to Brazilian law - Law No. 10,098, of December 19, 2000 -, a user with low vision have visual acuity between 0.3 and 0.05 in the better eye with best correction optics, or the sum of the measured visual field in both eyes equal or less than $60^{\circ}$ )[10]. Or even a user with physical disabilities, which takes an environment previously thought to have no architectural barriers or a readily movable movement and escape in 
an emergency. These scenarios are possible thanks to an information system thought to have the full accessibility that preaches universal design.

Cognitive science seeks choose the leveling descriptive of behavior, sign interpretations and observations and inferences about mental processes to reconstruct the processes of the tasks imposed implementation[4]. The cognitive effectiveness, in this case, search the informational efficiency as a catalyst for actions planned and programmed or until the unplanned and emergency actions and what, specifically in this case, can be a vital ally to the security and survival of the individual. The informational ergonomics, as scientific discipline that deals with the relationship and their peculiarities between man and communicational environment where information is inserted, combined with the concepts of universal design and ICT, ensures the concern for transmitting the information efficiently and effectively to any type of user, with or without disabilities, with the commitment of the correct perception of information in the shortest time.

\section{$4 \quad$ Final Considerations}

The current study is justified by its contribution with the union of ergonomics, cognition and technologies of information and communication as a way to attend the principles of the universal design to the development of accessible projects. The study regarding interactive museums, cognitive processes and ICT enables a variety of possibilities to be considered in the development of accessibility strategies for settings and informational systems, adjusting compatibilities to the needs and limitations of all users, with or without disabilities, thereby improving the human-information interaction. In the Kahal Zur Israel Synagogue, object of this research, the use of a great part of the technologies researched will be defended as facilitators and inclusive tools for the full and unrestricted access to settings and information.

The purpose of this article is not to end discussions about the information system, but collect data that may serve as an incentive for further research. It is intended, mainly, to make clear the importance of participation by ergonomics and design professionals from the stage at which the "museum" design project itself starts. By focusing projectuals guidelines under the lens of universal design, to have a project that, since their beginning, serves the public to the fullest.

It is also necessary to make a deep discussion of the subject with other professionals and researchers of the fields involved and alike, with the intention to evaluate the purpose and the paths taken in this research in favor of a more effective analysis. It was noticed during the bibliographic research a certain shortage of publications in the field, raising even more the importance of similar studies.

\section{References}

1. IBGE: Censo 2010. Instituto Brasileiro de Geografia e Estatística (2011)

2. Long, J., Whitefiled, A.: Cognitive Ergonomics and Human-Computer Interaction. Cambridge University, Cambridge (1989) 
3. Soares, M.M., Martins, L.B.: Design universal e Ergonomia: uma parceria que garante acessibilidade para todos. In: Almeida, A.T., Souza, F.M.C. (eds.) Produção e Competitividade: Aplicações e Inovações, pp. 127-156. Editora UFPE, Recife (2000)

4. Mace, R.L., Story, M.F., Mueller, J.L.: The Universal design File: designing for people of all ages and abilities. North Carolina State University School of Design, Raleigh (1988)

5. NBR 9050: Acessibilidade em edificações, mobiliário, espaços e equipamentos urbanos. Rio de Janeiro, Associação Brasileira de Normas Técnicas

6. Muchacho, R.: O Museu Virtual: as novas tecnologias e a reivenção do espaço museológico. Actas do III SOPCOM, VI LUSOCOM e II IBÉRICO, vol. I, Covilhã, Universidade da Beira Interior (2005)

7. Connel, R.: Processo Cognitivo e Comportamento Motor. In: Rodrigues, D (org.): Métodos e Estratégias em Educação Especial - Antologia de Textos, Lisboa, Faculdade de Motricidade Humana (1991)

8. Tani, G., et al.: Educação Física Escolar: fundamentos de uma abordagem desenvolvimentista. EPU, São Paulo (1998)

9. Schmidt, R.A.: Aprendizagem e Perfomance Motora. Movimento Ltda, São Paulo (1992)

10. Brasil: Decreto $n^{\circ}$ 5296, de 02 de dezembro de 2004. In: Diário Oficial da União, n. 232 (2004)

11. Silva, E.R.G., et al.: Processamento cognitivo da informação para tomada de decisão. In: Perspectivas em Gestão \& Conhecimento, João Pessoa, Brasil, vol. 1, pp. 25-39 (2011) 